\title{
Recent developments in biotech industry outside of the USA and Western Europe: Report from BIO 2005
}

\author{
Aldar S. Bourinbaiar \\ Immunitor USA Inc. \\ College Park, MD 20740, USA \\ Tel: 3014749369 \\ Fax: 7756406636 \\ E-mail: info@immunitor.com
}

Keywords: Africa, Asia, bioindustry, biotech, biodefense, Eastern Europe, Latin America, Pacific, Russia.

The BIO 2005 international convention is the largest gathering of the biotech industry in the world. This year it was held on June 19-22 inside the behemoth Convention Center in downtown Philadelphia, bringing together 18,730 executives, investors, consultants, lawyers, politicians, scientists, and dreamers from 56 countries. More than $\mathbf{5 0 0}$ media representatives covered the event. Biotechnology research and findings presented by countries outside the USA and Western Europe has begun to make a significant impact on these annual BIO gatherings. The achievements of some of these countries are briefly reviewed.

The world's largest and most prestigious biotechnology convention has just adjourned. BIO 2005, the US Biotechnology Industry Organization's $13^{\text {th }}$ trade show and convention was held this year in Philadelphia, PA. The BIO organization represents more than 1,100 biotechnology companies, academic institutions, state biotechnology centres and related organizations in all 50 US states and 31 other nations (www.bio.org). BIO members are involved in the research and development of health-care, agricultural, industrial and environmental biotechnology products. The BIO conferences started as a small gathering of biotech executives. The first convention, which was held in 1993, had only 1,400 attendees.

This year's BIO 2005 was co-hosted by the States of Pennsylvania, Delaware, and New Jersey. More than 200 companies delivered business presentations. More than 900 speakers shared their expertise in 180 program sessions. The exhibit hall featured a record 1,525 displays, with more than 60 state and international pavilions. The hall itself, despite having over 315,000 square feet of space, was completely sold-out. Walking through the enormous exhibit hall was a physical challenge akin to running a marathon.

BIO 2005 delegates made a huge impact on the economy of the city. Hotels, restaurants, taxis, etc., grossed an estimated \$ 35 million. At night, BIO 2005 became a city-wide party where delegates were proffered food and drinks at
Philadelphia landmarks, local hotels, restaurants and bars. On opening night, a cocktail reception was held at the National Constitution Center. The Philadelphia Museum of Art hosted a gala two nights later. The closing event was at the Philadelphia Cruise Terminal with many private receptions by individual companies and groups throughout the conference. One could eat and drink for free for all four days that the convention lasted.

Not everyone shared this enthusiasm for biotechnology, though. Security at the conference was extremely tight. A few dozen protesters and activists, rallying against everything from genetically modified foods to animal rights, took to the streets of Philadelphia on the third day of the event. In the scuffle with protesters one plainclothes police officer who was about to intervene suffered a heart attack and died on the way to the hospital. This was the only biotech-related casualty at the conference. The sight of protesters and clowns from the Cirque du Soleil was quite unusual to the unseasoned delegates.

This year's attendance supported the growing trend, that an increasing number of delegates from countries outside of the USA and Western Europe are now attending the BIO. Over a dozen international seminars were held to highlight their technology and several countries had pavilions or booths to capture delegates' attention. Latin America was represented by Chile and Argentina; Asia had by far the most prominent presence, including a one-hundred-strong delegation from Malaysia as well as representatives from South Korea, Japan, Taiwan, China, Singapore, and India. With the exception of the Czech Republic, Hungary, and Russia, no other Eastern European countries were visible. African countries had a few delegates but no booths were set up to mark their presence.

Given the potentially enormous economic benefit many countries have chosen to enter the global biotech race. Global capital investment in biotechnology industries reached \$ 21.2 billion in 2004, a 15\% increase over the capital raised in 2003. Many nations began considering the biotech as golden-egg-laying goose that could inject new 
life into their respective economies. Biotech is booming in Latin America, Eastern Europe, and even more markedly in Asia, where several countries - Singapore, India, China, Taiwan, Japan, and South Korea, to name a few - have allocated billions of dollars to promote bioscience research. A brief summary of what happened at BIO 2005 in biotech industry in nations outside the USA and Western Europe is provided below.

\section{LATIN AMERICA}

This continent, which represents 500 million individuals, appeared to have been presented by two countries only Argentina and Chile. Other countries in the region have attended the event but their presence was not very visible since they did not have booths. Delegates from Brazil, Mexico, Colombia, Uruguay, and Cuba had a session before opening of the convention where they shared their experience and challenges in engaging in bio business.

While the Latin biotech industry lags behind its Northern neighbour, the energy and passion of South American countries is impressive, as evidenced by the success story of Cuban biotechnology. Cuba has spent $\$ 1$ billion building a biotechnology program that is now among the most advanced in the developing world. In 1999 the Carlos Finlay Institute's meningitis vaccine was licensed to AngloUS pharma group GlaxoSmithKline - a deal worth \$ 150 million annually. At BIO 2005 breakout session the California-based CancerVax Company reported promising results from their trial of a lung cancer vaccine that was licensed last year from Canadian YM Biosciences and the Cuban Center of Molecular Immunology.

\section{Argentina}

The main biotech sponsor, Foro Argentino de Biotecnología (FAB), was established in November 1986 as a non profit foundation to promote biotechnology enterprises. Two national counselling commissions are actively involved along with FAB. One is the National Commission of Agricultural Biotechnology (CONABIA), which is in charge of giving advice to the National Secretariat of Agriculture, Food and Fishing. The other is the National Commission of Biotechnology and Health (CONBYSA), which belongs to the National Secretariat of Health. Argentine Technological Fund (FONTAR) is the main investor that so far provided US\$ 9.6 million to 20 companies. According to them $4 \%$ of total annual pharmaceutical drug sales (US\$ 2 billion) is generated by local biotech products.

Argentina's leading life science company is Bio Sidus S.A., which traces its origin to Sidus S.A. founded in 1938. The company gained its fame when in 2002 it succeeded in cloning the first transgenic cow to produce human growth hormone. According to Mirta Quintana, public relations manager, company also sells a variety of recombinant proteins such as erythropoietin, insulin, interferon, and granulocyte colony stimulating factor (GCSF). In addition it also manufactures plasmids and makes a whole range of genetically engineered plants resistant to herbicides and viruses.

Maria Mata, a representative of FAB, indicated that the local market needs in diagnostics and veterinary vaccines are mostly self-sufficient due to a strong native bioindustry sector.

\section{Chile}

Up-and-coming Chilean biotechnology was well presented at BIO 2005 with a spacious pavilion that had detailed information on the country's industry. In 2003 the government created National Biotechnology Development Commission, which adopted strategic development plan for Chile. The strategy seems to have paid off, with 95 biotechrelated organizations and at least 16 biotech companies currently in business. The incentives and tax cuts for biotech companies to install in Chile appears to be very generous which has triggered a stream of foreign companies coming to look at favourable business environments.

Canadian company PerOs Systems Technologies which was presented by Emiliano Rabinovich, has developed an interesting oral vaccine technology now being tested by its Chilean subsidiary for application in the fish and livestock industry.

The Chilean commitment to biotech is strong. For example, one of the applications of biotechnology of interest to this country is in transgenic or genetically modified plants. Chile, the Southern Hemisphere's largest exporter of fresh fruits, plans to cultivate transgenic crops. The goal is to patent and then plant new species of genetically modified grapes, nectarines and peaches for sale in international markets. Chile's exports of such fruits alone could grow in value by $\$ 140$ million.

The companies interested in opportunities in Chile should start by contacting Chilean Economic Development Agency and Chilean Association of Biotechnology Business.

\section{ASIA-PACIFIC REGION}

Asian countries and Australia/New Zealand are now poised to overtake the USA and Western Europe as leaders in the biotechnology industry. Based on 2004 data of Gurinder Shahi, the region's biotech expert from the think tank Global Bio-Business Initiative at the University of Southern California, the number of bioventure deals in Asia reached 3,200 , surpassing 1,500 and 1,800 deals made in the US and Europe respectively. Biotech revenues in the Asia Pacific region grew 36\%, compared to global industry revenues, which grew at $17 \%$ to attain $\$ 54.6$ billion. While most of innovative products still originate in the USA, and $78 \%$ of biotech revenues are generated there, it is clear that 
it is just a matter of time before this region dominates the global biotech market.

\section{China}

The ready-to-be-spent, surplus cash that China had accumulated as a result of its booming economy, combined with the reverse brain-drain trend, positions the nascent Chinese biotech industry in a "red alert" category for competitors. China possesses a huge asset to help it realize its high-tech dreams: the more than 300,000 students from mainland China who have been trained in foreign universities, mostly in the US and Europe. They are China's best and brightest, acquiring Western-style commercial savvy as well as familiarity with cutting-edge academic research. While US companies will keep a competitive edge by introducing innovative, patent-protected technology, Chinese scientists returning home are applying US-acquired know-how into making competitive products.

The Chinese market is now flooded with locally-made generic biotech products which, like Indian vaccines, will drive down the global market prices dramatically. Founded in 1997, GenSci is a typical Chinese biogeneric company. It employs 4,000 people with an annual \$20 million in sales of recombinant growth hormone, GMCSF, and interferon. Unfortunately, counterfeit drugs are still common in China, including forged imitations of popular biotech products, as evidenced by prominent warning on GenSci's website.

While China's pavilion at BIO 2005 appeared very modest one should make no mistake in assuming that its biotech industry is backward. US companies and universities may well find themselves seeking access to cutting-edge Chinese biotech, rather than the other way around. In fact, foreigners are now increasingly common as staff in Chinese companies. Lanna Cox, business manager of CapitalBio is one of them. CapitalBio is a biochip company that was started by US-trained Chinese expat, Chen Jing. The company's pioneering work "Lab on a Chip" has been cited by Science magazine as one of the top ten scientific breakthroughs in 1998.

"Speed Inc.", must have been more appropriate name for Beijing Genomics Institute. Formed in 1999 by Yang Huanming, a researcher trained in Europe and the US, the institute sequenced the genome of a strain of rice in about four months--a stunning feat, given that in 1998 an international group convened to decode the rice genome estimated that it would take a decade.

China's entry into the World Trade Organization, in December of 2001, opened the door to a lucrative market for foreign companies, and especially for pharmaceutical manufacturers. Prior to that one of the major risks for foreign companies has been the threat to their intellectual property, but now "China will be bound by WTO principles, such as improved transparency and the strengthening of legal procedures" said Mark Tang,
President of World Technology Ventures, an investment firm based in New Jersey. China's WTO commitments will help reduce the risk of doing business in China and encourage increased trade and investment flows.

\section{India}

India is by far the heaviest player in Asian biotech's weight contest. The country's presentation at BIO 2005 was standing room only - the conference room had three times as many people as it was designed to contain. India's recent patent law conforming the country to WIPO rules may have triggered the interest. Obviously, the tremendous success of India's pharma and biotech, especially vaccine industry, has been the critical factor that drew intense interest.

Mr. Kapil Sibal, the ebullient head of the Ministry of Science and Technology and vocal champion for biotech cause, has summarized advantages of India. The low-cost labour and manufacturing capabilities, combined with more open policy and more secure IP protection, are factors that will attract outsiders. The protective policy favouring domestic companies that has pushed out most foreign companies has been declared history. This policy over time, however, allowed native companies to carve a niche for themselves. Their low-cost products now dominate India and most of the developing world.

Vaccine companies were leaders in this movement. Serum Institute of India is the leading company in the country. Company produces about 675 million doses a year, to supply one third of global demand in vaccines. Yet, Serum's turnover is a mere \$ 110 million, while GlaxoSmithKline (GSK), which produces 780 million doses, makes $\$ 2$ billion.

India's biotech sector now has over 280 companies. This year total revenues from Indian biotechnology recorded a $36 \%$ growth and the US\$ 1 billion mark in sales has been officially attained. Of course, compared to US companies that brought in \$ 47 billion and recorded 29\% growth in 2004, this might be a modest figure. However, "when one considers five-times cheaper cost of developing a product in India, it is difficult for Western countries to compete with us", says Suresh Dhawan, Chief Executive of the biotech park at Genome Valley -state-of-the-art biotech cluster next to Hyderabad. Other states in India are catching "bio revolution" waves by setting up similar parks to attract new businesses. Karnataka state calls its capital Bangalore, "Biocity", a statement that may be justified, considering that at least 85 biotech companies are now in the city.

In general, the agricultural biotechnology research is the largest sector in the developing world. Many Asian governments, including India, have given high priority to plant or agrobiotech with the hope of addressing the pressing needs of growing population to be fed and clothed. Much of GM crops in India, as pretty much elsewhere in the world, are still supplied by Monsanto. New agrobiotech 
companies like Metahelix, however, are emerging to assist crop improvement.

\section{Japan}

The sluggish Japanese economy could certainly use a boost from the biotech industry. Anybody coming to the Japanese pavilion could see its outpost - the bright red-on-white stand of Japan External Trade Organization, or JETRO. Its role, among others, is to promote Japanese biotech. The government has identified the biotechnology as one of the five main industries geared to help turn around the economy. Japan has long hosted powerful pharmaceutical houses but more recently has concentrated its effort in the narrower biotech field. Unlike in the US, where small entrepreneurial companies pioneered biotech, large established Japanese companies were the pioneers in Japan's early biotech industry. "The biotech market is becoming more attractive because of the plateau in pharmaceutical industry's growth", says Yasuhiro Takahashi, President of Biolink International - a consulting firm specialized in biotechnology deals.

The Japanese biotechnology is the second largest in the world. According to JETRO, revenues from goods and services in the biotech sector reached $\$ 17$ billion in 2004, with the goal of reaching $\$ 240$ billion in 2010. More than 460 biotech companies are now registered in Japan compared to 100 a decade ago, and the government expects that number to reach 1,000 by 2010 .

The rapid rise in start-ups is due in large part to fundamental changes in the way Japan was regulating and doing business. In 2000 and 2004 new laws were introduced that allowed transfer of technology from universities and no longer prohibited researchers at universities to hold executive positions in private companies. Before that, there was no formal way for universities to spin-off their inventions into the private sector.

Many of 50 companies at Japanese pavilion seem to have been borne from this initiative. Ken Tanigawa, CEO of Beacle Inc., nanotechnology company that develops drug delivery based on use of virus like particles, is happy with his venture that was started only three years ago by teachers at Okayama and Osaka Universities. "I am spending all day meeting with companies interested in our technology," Tanigawa said.

As privatization is taking hold, there is an increasing number of private venture capital firms investing in biotech - a phenomenon quite unusual and new for Japan. Present at BIO 2005 was Masahito Wada, PhD, - the deputy manager of Tokyo Small and Medium Business Investment \& Consultation company. "According to industry analyst Thompson Financial”, said Dr. Wada "my firm is ranked first by reportable fund size even though few people outside Japan have ever heard about us".
The government is also prioritizing funding for biotechnology. The asked budget for the new fiscal year is \$ 3.1 billion, a 29\% increase over 2004. JETRO is aggressively courting private companies to provide more money to bolster biotech revenue streams. Japan is devoting enormous resources to developing its infrastructure, growing bioclusters, conforming to international standards, reducing regulation, and nurturing its talent pool to attract biotech business, observers say. If Japan will continue this trend, a bold, new biotech generation may arise that will break away from the old model that relied on flagging pharmaceutical industry.

\section{Malaysia}

Malaysia is a relatively late entrant into Asian biotech race. Yet by far, the new government's policy in promoting this new sector is most impressive. This year, Malaysian delegation had the largest number of participants among Asian countries. Considering that each paid US\$2,000 in registration fees, plus travel and accommodation, the government must have spent close to one US\$ million just to attend the event. Government has set up several venture funds to nurture biotech industry. Provided companies are willing to settle in Malaysia, these funds will offer them an unparalleled opportunity to jump-start the business in specially built Biovalley near Kuala Lumpur's International Airport.

With his first name a legacy to Alexander the Great, Mr. Iskandar Mizal Mahmood, the resolute CEO of Malaysian Biotechnology Corporation had no hesitation in expressing confidence in a great future for Malaysian biotechnology. Other government venture funds such as Malaysian Technology Development were equally present at the Malaysian pavilion and were very candid about their intention to create favourable conditions for the integration of foreign companies. As of May 2005 MTD had already funded 105 companies - a record number for any venture company.

Malaysian biotech companies, already in business, offer a remarkable array of products. For example, diagnostic company, MBDr, run by energetic Professor Ong Kok Hai, has unique kits for detecting tropical diseases that are not available anywhere else in the world. Veterinary vaccine company -a joint venture with Australian Arthur Webster company- had a long list of commercial animal vaccines that are now being exported to a number of countries.

Other companies that were set to explore rich biodiversity and agrobiotech business of Malaysia were showcased at the convention. Straight-talking Prof. Farida Habib Shah, director of Melaka Institute of Biotechnology and one of earliest supporters of biotech initiative, indicated her satisfaction with the current trend of bridging research and industry needs.

Another attractive business opportunity for Malaysia is in 
sourcing clinical trials. For international CROs like UKbased Medical Matters International, directed by Dr. Michael Bowles, the quality of medical services combined with reasonable cost is the main reason why he likes to conduct clinical trials in Malaysia.

Clearly, Malaysian heavy investment in life sciences is likely to produce far-reaching dividends for the country.

\section{Singapore}

This miniscule city-state provides an example as to how bold and visionary strategy to invest in the life sciences pays off after a very short period of time. Size no longer matters, at least in biotechnology world. Intelligence, education and the ability to adapt to changes and to capture biotech opportunities has become the key to Singapore's national prosperity. A generous package of tax cuts, grants, loans, and other incentives has lured small and multinational companies alike. The infrastructure support has been essential in Singapore's ability to attract outsiders. Recently Singapore opened yet another incubator, Biopolis, to house 1,500 biotech scientists and their companies. Biopolis represents \$300 million dollar commitment to move away from the electronics focus, which helped the island to transit from "third world" country to first.

According to Kevin Lai, head of New York office of Singapore's Economic Development Board, profits generated by biotech and pharma companies now contribute between 9 to $14 \%$ to the national revenue. No wonder that many countries are trying to reproduce the success story of Singapore. Companies and entrepreneurs wishing to install in Singapore may need to contact the Agency for Science Technology and Research a.k.a. A*STAR or Bio*One Capital, a subsidiary of EDB financial service. Both these organizations manage venture capital funds that invest in strategic biotechnology and medical technology companies and start-ups in order to facilitate the growth of the vibrant biomedical sector in Singapore.

Bioprocessing Technology Institute (BTI) is one of many tenants at Biopolis supported by A*STAR. BTI pursues innovative and cutting-edge research to exploit the potential of human embryonic stem cells (hottest topic at this year's $\mathrm{BIO}$ ) and to improve the output of recombinant proteins from cell culture. "I have great future", says Sheng-Hao (Jimmy) Chao, a research scientist who had just moved to BTI from George Washington University in Washington, DC.

Provided this island will continue attracting young and cosmopolitan talent, the future will be more predictable -at least more so than $19^{\text {th }}$ century Liu I-Ming's interpretation of the I Ching, the Chinese book of divination, also known as the science of the Gold Pill.

\section{South Korea}

According to Science magazine Dr. Hwang Woo-seok's breakthrough in culturing human stem cells from nonembryonic tissue became "one of the top ten research achievements in 2005". The dream of becoming bioengineering leader is taking shape as solid reality in Korea. The biomedical science in Korea started in early 1960 's. The government at that time created several research institutions -the names of all of them started with capital "K", e.g., KIS, KAIST, KRIST, and KRIBB. Since the late 1990's, the ideas and projects carried out at these institutes have been encouraged to spin-off into biotech companies. Government played very active role in this process.

According to Robert Mitani, Korean biotech consultant based in New York, there are close to 500 companies currently registered. This is an astonishing number considering that US has 1,500 biotech companies. The average growth in last 3 years was 25\%. At this rate bioindustry will overtake IT industry by 2010. In keeping with this trend the LG, the largest electronics manufacturer, is also becoming the power house in the biotech sector. In 2004 LG Life Sciences Ltd. had signed contract with the United Nations for supply of its hepatitis B vaccine, EuvaxB - a deal valued at around \$ 22 million. LG's quinoline antibiotic, Factiva, became the first Korean drug to be approved by the US FDA, opening a new chapter in Korea's biotech industry. Right now only limited number of companies such as Korean GreenCross Vaccine Corporation, a wholly owned subsidiary of Swiss Berna Biotech, have commercial products, but situation is predicted to change in 2-3 years from now. The International Vaccine Institute, the world's only international research organization devoted solely to bringing new vaccines to the poor countries is based in Seoul's first biotech incubator.

Korea has initiated several other grand incubator projects. For example Songdo Bio Complex calls for the creation of a whole city with a quarter million inhabitants who will devote themselves exclusively to biotechnology. Osong Bio-Health Science Technopolis is another ambitious project located $30 \mathrm{~min}$ from Seoul. The area of 4.6 millions square meters will have a brand-new city with a population of 100,000 who will be working at the Korean FDA, NIH, CDC and various government or private biotech institutions and companies. Various attractive incentives are offered to companies wishing to establish business in Korea. More details are available at the Ministry of Commerce, Industry, and Energy website.

\section{Taiwan}

Taiwan's biotechnology and pharmaceutical sectors registered a total production value over US\$ 3 billion. In addition to 425 pharmaceutical companies and 380 medical device companies, over 100 "pure" biotech firms are registered in Taiwan. 
According to David Silver from Taipei-based BiotechEast Co., Ltd., who covered the public relations jointly with the Biotechnology and Pharmaceutical Industries Program Office of Taiwan's Ministry of Economic Affairs, the visiting delegation this year had around 150 delegates. Taiwan typically sends the largest group from Asia. In addition to BPIPO other government groups were the Industrial Development Bureau (IDB), National Science Council, the Department of Health, the National Science and Technology Program for Agricultural Biotechnology, the Science and Technology Advisory Group (STAG), the Council of Agriculture, and the Taiwan External Trade Development Council (TAITRA).

Academic and research groups were represented by the leading institutes in their fields -Academia Sinica, the Industrial Technology Research Institute and the Development Center for Biotechnology.

Private companies present at the booths this year included Taigen Bioscience, a biotech instrumentation and services company; Mycenax, a contract manufacturer of biopharmaceuticals; Targetgen Biotechnology, a maker of biosensors; Apex International, a contract research organization; and Advanced International Pharmaceutical Nanotech, a producer of nanotech-derived health foods and cosmetics. Taiwan is particularly strong in the area of traditional Chinese medicine -SunTen Phytotech, a herbal medicine/drug discovery company has several products in advanced clinical trials and already markets two "botanical” drugs.

This year it was first time that Taiwan had the honour to present at the International Country Seminars. During the convention Taiwan made an announcement of collaboration between ITRI and Australia's leading research institution, CSIRO. Taiwan's pavilion hosted visits from regional political figures, including the Director of the Missouri Department of Economic Development, Greg Steinhoff and Governor of Ohio State, Bob Taft. Anyone who is interested to learn more about biotech opportunities in Taiwan can start by viewing the Ministry of Economic Affairs website or write to David Silver -the veteran analyst of Taiwanese bioindustry (www.biotecheast.com).

\section{Australia}

Australia is counting on its down-under insight for innovation, unblemished respect for intellectual property, and upbeat Aussie spirit to support biotechnology startups and companies seeking to relocate their operations.

Many of Australia's 40 universities have strong biotechnology programs and provide the basis of much of Australia's research. The flu drug, Relenza, and the new papilloma vaccine for cervical cancer were both discovered in Australian labs. Compared to 2001 the number of biotech companies doubled. Approximately 400 biotech companies call Australia home, of which $46 \%$ are in human therapeutics, $16 \%$ in agricultural biotech and 15\% are diagnostics companies. The government has thrown in considerable funds for building biotechnology business, according to the key biotech sponsoring groups Ausbiotech, Austrade, and Invest Australia. Companies considering expanding into Australia will find plenty of private investment dollars as well. The Australian Venture Capital Association Limited (AVCAL) is the national association that represents the venture capital industry players. Its members have A\$ 10 billion invested or available for investment. Angels, like charismatic Peter Boonen, who invested in a patented growth agent, which he publicly listed through animal health biotech company Stirling Products are, however, less common in Australia than in the US. Boonen's more recent biotech investment is through his California-based MDM Group -in biodefense-related projects and oral fluid testing assets.

The country has remarkably streamlined drug regulatory process. Theoretically, it is possible to have a clinical trial approved within a week by the Australian Therapeutic Goods Administration under the Clinical Trial Notification scheme. This regulation is certainly attractive for many companies who want to expedite their drug pipeline.

\section{New Zealand}

If not for the Tolkien trilogy, New Zealand might have remained a small country in the middle of the ocean, to which few people would have given much thought. However, its open economy, lack of bureaucracy, and firm support from the National BIO Organization have the biomedical industry taking a hard look at New Zealand.

Currently, the land is home to 40 core biotech companies and another 300 companies involved in service and support, and the industry employs approximately 3,900 people. New Zealand's biotechnology sector exports were worth \$250 million in 2003.

According to New Zealand Trade and Enterprise more than half of the biotechs in the country were founded in the past three or four years. The New Zealand government in recent years has taken steps to make the environment more inviting for startups and companies that are relocating. The government has created grants to aid with product development as well as training of scientists. The government has supported establishment of a venture investment fund, which offers matching dollars from both government and the private sector.

A number of additional groups promote the biotechnology industry in New Zealand. They include Invest New Zealand and The Foundation for Research, Science and Technology, which invest over \$ 460 million a year in research, science and technology. The country recently signed the Biotech Alliance with Australia, which seeks to raise the profile of both countries in the international arena and build a more collaborative relationship between the two. This alliance is 
expected to create greater regional critical mass and impact.

\section{Israel}

Israel's biotech industry is strong. Israeli companies are involved in a variety of biotechnology activities, including therapeutics, diagnostics, bio-informatics and agro-biotech. One key to country's success has been its unparalleled brainpower and its emphasis on education. Israel has very large number of research institutions, hospitals, and universities (www.science.co.il). One third of all Israeli scientists, many of whom are immigrants from the former Soviet Union, are in the life sciences.

According to ILSI - the national umbrella organization for biotech businesses -Israel's life sciences sector encompasses more than 500 companies. Israel has never been short of ideas. Israel occupies third place in the world by number of filed life science patents. Israel has strong government commitment and private venture capital sector to get new ideas off the ground.

There are several sources of capital which total somewhere between $\$ 800$ million to $\$ 1.0$ billion at any given year. The funding comes primarily from the government (30.3\%) much of which is coordinated through the Office of the Chief Scientist at the Ministry of Trade and Industry; competing grants (12.8\%); and venture capital (28.2\%); the rest of money is raised by companies' own efforts. Socalled binational foundations with other countries, like Binational Industrial Research and Development foundation between US and Israel have proven to be effective mechanisms for making good return on investment.

While most Israeli biotech companies are in their early stages and still located at university campuses or nearby incubators, some are emerging to become household names in the global biotech arena. Best known example is Teva. Annual sales of Copaxone, the first effective peptide drug for multiple sclerosis developed by Teva, has broken through the billion dollar barrier this year. Considering country's small market Israeli companies must look at their business from more global viewpoint and encourage partnership -a strategy that has paid off for Teva.

\section{EASTERN EUROPE}

This part of Europe has been historically self-reliant on its own bioproducts. After collapse of the centralized communist economy the countries in this region are now striving to set up sustainable biotech industry as part of their transition to a market economy. Due to legacy of advanced education and creativity in problem solving on a shoestrings budget, there is no lack of innovative ideas and products. However, the traditional venture capital to fuel the biosector is scarce and countries are using various strategies to achieve their goals.

\section{Czech Republic}

This former socialist country has a long tradition of innovative basic research but due to budget constraints the modern biotech industry is still in early stage. CzechInvest is a government agency that promoted the Czech Republic at BIO 2005. The Czech government is helping to establish biotech incubators that will bring together universities, research institutes, and start-up biotech companies. The government has invested money into the country's 29 universities, which along with 21 life science related institutes of the Czech Academy of Sciences constitute the rich source of brilliant ideas. While university-based researched has gained worldwide recognition, commercialization remains slow.

Recent successes, however, include funding for a targeted chemotherapy treatment developed at the Institute of Microbiology. The treatment is poised to move into more advanced clinical trials with the support of Zentiva, one of the top five Central and Eastern European pharmaceutical groups. A couple of companies like CLONESTAR and EXBIO, spin-off companies of Czech Academy of Sciences and local universities are now selling custom-made peptides and antibodies on the European market. Founded in 1958, Sevapharma is country's main manufacturer of vaccines and interesting immunobiological preparations that are exported to countries as far as Vietnam. Due to highly educated and relatively inexpensive labour force the country started to attract foreign companies. In June 2004, Baxter opened second state-of-the-art facility for the production of cell-culture derived and recombinant vaccines such as influenza vaccine.

Tomas Novak, Director of CzechInvest office in California, is optimistic about the future of country's biotechnology. During the conference he reported a number of impressive research breakthroughs in stem cell research, targeted chemotherapy, AIDS and Alzheimer's therapies. These advances could potentially create the competitive springboard for Czech bioindustry. The Czech republic along with several other Central and Eastern European countries had recently joined the European Union (EU). These countries will certainly benefit from the influx of funds provided by the EU.

\section{Hungary}

Hungary's Minister of Economy Janos Koka, who attended BIO 2005, is confident that Hungary's biotech industry can lead the EU in research and development. This country has the largest number of Nobel prize winners per capita. Many of these laureates had their prizes in chemistry, which perhaps is why this country has been particularly strong in conventional drug Research and Development. But "the pride of old days' Hungary, prosperous pharma industry, that supplied the needs of most of the communist bloc countries, is barely surviving -- peddling generics or bought lock-stock-and-barrel by multinationals”, says Dr Peter Csepes, Hungarian industry analyst based in New York. A few, like Richter Gedeon and Egis seem to have escaped 
this fate and re-invented themselves in the transition period.

Hungarian Biotechnology Association was formed in 2003 and now has about 30 companies on board. In January 2004 the government created the Research and Technology Innovation Fund which will hand out about \$ 213 million each year, with substantial amount of this money expected to go to biotech research. The fund's money will come in equal proportions from the government and from Hungary's 26,000 private companies, who will be paying at least $0.25 \%$ of their turnover into the fund as an "innovation contribution". Hungary being now the member of the EU, will make best out of its human capital, strong Research and Development tradition, and funds available to build strong biotech industry.

\section{Russia}

It is a big country with big ideas but unfortunately often short on cash. Last year the US Department of State sponsored more than 100 scientists and biotechnology industry representatives from Russia and other former Soviet republics to participate at BIO 2004. This year Russians were represented by Mid-Atlantic-Russia Business Council -a local organization based in Philadelphia. The Russian pavilion like the one in San Francisco was nowhere to be found. Despite this setback the biotechnology in Russia is on the right track. In 2005 the Russian Parliament, Duma, introduced a 10-year plan to promote biotechnology. Allocated funds for this plan will help strengthen the areas that have been historically strong in Russia and are being pursued by over a thousand research institutions throughout the country. One of the largest-scale programs in this area is the Biotechnology Consortium for Medicine and Agriculture (BIOMAC).

Some of Russia's unique expertise, such as bioweapons' development, is being turned into more peaceful purpose as a part of non proliferation program initiated by the US Department of State. The US companies like MDM, engaged in potentially lucrative biodefense projects, stand to profit from collaboration with Russian experts in designing more effective medicines and vaccines against bioterror bugs. Bioterrorism expert, Dr. Edward L. Stephen, who was recently appointed to lead MDM's Biodefense Division, just came back from a month-long trip in Russia. The agreement signed with the Russian BIOMAC, "creates an immediate and important extension to the scientific capabilities and the facilities available to us," said Stephen. "With the help of Russian experts we started developing a safer and more potent smallpox vaccine that may become the vaccine of choice for homeland security”, he added.

\section{CONCLUDING REMARKS}

According to Steve Burrill -the guru of biotech industry"outside the US-Europe, the biotech in China, India, Eastern Asia and Australia will be more robust. These countries will continue to contribute new technology, increasingly become markets for biotech products and sources of capital, as biotech becomes an increasingly global industry".

The next year's BIO Convention will be held in Chicago. Countries that want to seriously consider biotechnology as a driving force in their future prosperity need to attend this single, most powerful gathering in the world. Attendance at BIO is a must to those who wish to make deals and build strategic alliances. Comfortable walking shoes are another must. 